\title{
Public-Private Technology Partnerships
}

\author{
Promises and Pitfalls
}

\author{
JOSEPH E. STIGLITZ \\ SCOTT J. WALLSTEN \\ Stanford University \\ The World Bank
}

\begin{abstract}
The U.S. government has a long history of supporting private sector research and development $(R \& D)$. The economic justification for government $R \& D$ support is clear. Primarily because of knowledge spillovers, profit-maximizing firms invest less than the socially optimal level of $R \& D$. This market failure creates the possibility that government can help mitigate the underinvestment problem. Public-private technology partnerships are the newest approach to funding $R \& D$. Technology partnerships include public funding of industry-led $R \& D$ projects and private research consortia, and collaborations between industry and government scientists. These programs hope to generate research that yields commercial products and innovations. This article discusses the rise of these programs, the theory supporting them, the types of research projects they must fund to be successful, the technical and political obstacles they face in funding these projects, and the evaluations of the largest partnership programs. This article concludes with policy recommendations, recognizing that these programs have potential but must overcome significant hurdles.
\end{abstract}

The U.S. federal government has a long history of supporting private sector $\mathrm{R} \& \mathrm{D}$. Indeed, the Constitution gave Congress the right to grant patents to "promote the progress of science." Until recently, however, most federally funded industrial R \& D was directed at government needs, such as large weapons systems. Concerns about lagging U.S. productivity and increasing competition from U.S. trading partners in the mid-1980s and the subsequent end of the Cold War began to change the focus from government needs to government funding of commercial R \& D. The end of the Cold War posed a challenge. Previously, Cold War research had funded a host of projects that eventually led to innumerable commercial projects of immense value. Although these projects were typically not undertaken to advance commercial technology, it was one of the clearly beneficial byproducts. Indeed, popular support for federal research undertakings such as the space program was maintained, in part, by frequent references to commercial spin-offs. With the end of the Cold War, the government began to put even more emphasis on research leading to commercially viable outcomes. 
In 1993, the newly-elected Clinton administration put technology - and public support of private $R \& D$ in particular-at the center of its economic agenda, stating that "government can play a key role in helping private firms develop and profit from innovations" (Clinton \& Gore, 1993).

Many types of public-private technology partnerships have been implemented in the last decade. These range from direct public funding of industryled R \& D projects, to public funding of private research consortia, to collaborations at the national laboratories between industry and government scientists. All of these programs share the goal of generating research that yields commercial products and innovations. The economic justification for these programs is clear. Theory predicts, and many empirical studies confirm, that profitmaximizing firms invest less than the socially optimal level of R \& D. Government support of private $\mathrm{R} \& \mathrm{D}$ can help rectify this market failure. Sound theory does not always translate easily into sound policies. These programs must overcome enormous technical and political challenges if they are to succeed. Indeed, preliminary evidence on the effectiveness of these programs is mixed, at best.

In this paper, we first discuss the theory behind government support of R \& D in general, and government support of industrial R \& D in particular. We then discuss the rise of public-private technology partnerships over the past decade. Next, we consider the types of research projects these programs must fund if they are to be successful and the obstacles they face in achieving this goal. After the theoretical discussion, we highlight the largest and most prominent of these programs. This section also discusses the available evidence on the effectiveness of these programs. Finally, we conclude with policy recommendations, recognizing that these programs have potential, but that they also must overcome significant hurdles in order to be successful.

\section{WHY DOES GOVERNMENT FUND R \& D?}

Investments in $\mathrm{R} \& \mathrm{D}$ are crucial for economic growth, accounting for at least half of all increases in per capita output (Griliches, 1992). In fiscal year (FY) 1997 , the United States spent about $\$ 205$ billion on R \& D. Industry provides the majority of R \& D funds-approximately $\$ 133$ billion in FY 1997. The federal government provides most of the remainder-about $\$ 67$ billion in FY 1997 , almost $\$ 20$ billion of which went to industry. Table 1 provides a breakdown of U.S. R \& D spending by performer and source of funds. Industry funds the majority of product-related research (i.e., applied R \& D) whereas government funds the majority of fundamental (i.e., basic) research. Although much federal $\mathrm{R} \& \mathrm{D}$ is for specific government needs, government funding is crucial to economic growth because market failures cause firms, which act in their own best interests, to underinvest in R \& D from society's perspective. 
TABLE 1: Source and Performers of R \& D in the United States, 1997 (all figures in millions of dollars)

\begin{tabular}{|c|c|c|c|c|c|c|}
\hline \multirow[b]{2}{*}{ Performer } & \multicolumn{5}{|c|}{ Source of Funds } & \multirow[b]{2}{*}{ Total } \\
\hline & $\begin{array}{c}\text { Federal } \\
\text { Government }\end{array}$ & Industry & $\begin{array}{l}\text { Universities } \\
\text { and Colleges }\end{array}$ & $\begin{array}{c}\text { Other } \\
\text { Nonprofits }\end{array}$ & $\begin{array}{l}\text { Nonfederal } \\
\text { Government }\end{array}$ & \\
\hline Government & 16,450 & & & & & 16,450 \\
\hline Industry & 20,787 & 130,631 & & & & 151,418 \\
\hline $\begin{array}{l}\text { Universities } \\
\text { and colleges }\end{array}$ & 14,285 & 1,710 & 4,457 & 1,759 & 1,821 & 24.031 \\
\hline $\begin{array}{l}\text { Other nonprofits } \\
\text { Industry }\end{array}$ & 2,900 & 967 & & 1,653 & & 5,520 \\
\hline $\begin{array}{l}\text { FFRDCs }^{\mathrm{a}} \\
\mathrm{U} \& \mathrm{C}\end{array}$ & 2,273 & & & & & 2,273 \\
\hline $\begin{array}{l}\text { FFRDCs }^{\text {ab }} \\
\text { Nonprofit }\end{array}$ & 5,405 & & & & & 5,405 \\
\hline FFRDCs $^{a}$ & 644 & & & & & 644 \\
\hline Total & 62,744 & 133,308 & 4,457 & 3,412 & 1,821 & 205,742 \\
\hline
\end{tabular}

SOURCE: National Science Foundation, 1998.

NOTE: Figures are preliminary estimates.

a. FFRDCs: Federally-funded R \& D centers.

b. U \& C: University and college.

\section{THE PRIVATE SECTOR INVESTS TOO LITTLE IN R \& D FROM SOCIETY'S PERSPECTIVE}

Investments in $\mathrm{R} \& \mathrm{D}$ have very high returns and are a key component to economic growth. Under different assumptions, economic theory can explain why firms may underinvest or overinvest in R \& D. ${ }^{1}$ Empirical research, however, demonstrates that the private sector invests less than the optimal level in R \& $D$. Jones and Williams (1997) estimate that actual total R \& D spending in the economy is less than one quarter the optimal level. Underinvestment occurs because firms cannot appropriate all the returns to their $R \& D$ investments and because capital market imperfections may make financing $R \& D$ more expensive than other investments.

From the firm's perspective, $R \& D$ is like any other investment. The firm invests in $\mathrm{R} \& \mathrm{D}$ until the expected risk-adjusted private returns of the last research project equals its costs. Average returns on $\mathrm{R} \& \mathrm{D}$ to the firm are high$20 \%$ to $30 \%$, on average — but the returns to society are even higher-often $50 \%$ or more. ${ }^{2}$ These R \& D spillovers occur as others use research results and extend them in directions the original innovator often could not have imagined. Spillovers mean that an innovator is compensated for only a fraction of the total returns on $R \& D$. As a result, firms invest less in $R \& D$ than they would if they reaped all the rewards to their investments. In other words, some research projects that would yield positive net total benefits (i.e., the sum of private and social benefits less the project costs) are privately unprofitable because the investor does not see the social returns. ${ }^{3}$ Without some intervention in the market, the private sector 
will not undertake these research projects, although it is in society's interest for them to do so.

In addition to investing in less $\mathrm{R} \& \mathrm{D}$ than society would like, firms may invest less than they want if they do not have sufficient access to capital for R \& D. Capital market failures could arise if an innovator is reluctant or unable to provide financiers with enough information to evaluate a research project for fear of revealing too much about the proposed idea. Moreover, R \& D cannot be collateralized, unlike investments in machines or buildings. Firms may therefore be forced to pay higher rates of interest on loans for $\mathrm{R} \& \mathrm{D}$ than charged borrowers financing other, collateralizable forms of investment, or they may have to rely more extensively on internal funds (see Hall, 1992; Himmelberg \& Petersen, 1994). Because funds are fungible, firms with sufficient internal cash flow can, of course, resort to those funds for research, using collateral to finance investments in plant and equipment. The fact of the matter is that many high tech firms would like to invest more in research than they can finance through cash flow and collateralized loans. Schumpeter (1939) called attention to these constraints long ago. The evidence of the impact of changes in cash flow on R \& D investment, however, must be interpreted with caution, because events that adversely affect cash flow may also adversely affect the firm's net worth and ability to bear risks (see, e.g., Greenwald, Salinger, \& Stiglitz, 1991).

The fact that there is overall underinvestment in $\mathrm{R} \& \mathrm{D}$ does not mean that there may not be overinvestment in certain types of research. The most obvious example is alleged pharmaceutical research attempting to innovate around a patent. The objective of firms engaged in such research is not so much to produce a better drug (though that may be an unintended byproduct), but to divert the "monopoly rents" of an existing patent holder toward themselves. There can also be excessive expenditures in a patent race in which the marginal contribution - the earlier arrival of the innovation compared to when it would otherwise have arrived-may be small compared to the average return. This is a variant of the "common pool" problem. Some of the return represents the embodiment in the patent of commonly available knowledge."

\section{TRADITIONAL GOVERNMENT SUPPORT OF R \& D}

The existence of a market failure opens up the possibility that government can help mitigate the underinvestment problem. The government has traditionally used many tools to promote science and technology. Some methods, such as the patent system and research tax credits, are indirect. The patent system-enshrined in the Constitution and probably the oldest tool for promoting R \& D-increases the potential profits from an innovation. Because an innovation is costly to develop but often inexpensive to duplicate, the patent system grants a temporary monopoly to an innovator. Temporary monopoly rights provide an incentive to invest in research by creating the potential to profit off an innovation before others can use it. Patents, however, entail a high social cost. 
Knowledge is a public good in the sense that the marginal cost of an additional individual using that knowledge is zero. There is thus a trade-off between static inefficiency, associated with the underutilization of knowledge, and dynamic inefficiency, associated with the underproduction of knowledge. That is, once knowledge has been produced, it is inefficient to prevent others from using it, but if anyone can use it without cost, there will be little incentive to undertake the investments necessary to produce that knowledge. The rules for intellectual property rights attempt to strike a balance, for example, by choosing the length of the patent's life and the breadth of the discovery the patent covers.

Research tax credits-a much newer device, having been implemented in 1981 - decrease the cost of doing research to the firm by giving the firm a tax credit for a portion of its $R \& D$ expenditures.' A credit provides an incentive to increase $R$ \& D investment by reducing the cost of any research project, making any given project potentially more profitable. The $\mathrm{R} \& \mathrm{D}$ tax credit is actually a credit on incremental expenditures. As such, its impact on the long-run level of expenditures might be expected to be more limited. There are also concerns about whether all expenditures qualifying for the incremental R \& D tax credit really are research and development (e.g., should marketing research really qualify for the tax credit). The $\mathrm{R} \& \mathrm{D}$ credit, of course, does not attempt to distinguish between research that has a high level of spillovers and research that does not.

The government also directly funds R \& D. As noted above, the government funds the majority of basic research, where market failures are presumably greatest. Much of government support for basic research goes to universities and colleges. Basic research is crucial for long-run growth and is a key ingredient in more applied R \& D. Commercial products and innovations, however, are rarely the stimulus for basic research and often come years after the research is completed. For that reason, and because commercial applications of basic research are rarely obvious, firms have little incentive to fund basic research on their own. There is little disagreement that government must take the lead in funding basic research and training scientists (presumably because the total returns to society from their activities are in excess of the returns they appropriate).

Much of government-direct R \& D funding goes to applied R \& D in industry, although the extent to which government should support industrial $R$ \& D is more controversial. Traditionally, most of this funding has been to satisfy government objectives like space, defense, and, especially recently, health research directly. Although market failures may be less extreme in applied $R$ \& $D$ than in basic research, they still exist. Even the most applied R \& D is inherently risky and can generate large spillovers.

Government support of R \& D has generally been successful in helping to mitigate the underinvestment problem. Each dollar in research tax credit appears to generate more than a dollar in private R \& D spending (Hall, 1993). Direct government spending also seems to stimulate additional private spending on both basic and applied research (Hill, 1995; Levy \& Terleckyj, 1983; Robson, 
1993). Although most federal $R \& D$ was not intended to yield commercial products for civilian use, it would often spin off into commercial use. As the Council of Economic Advisers (1995) noted, in this manner the government "supported the development and diffusion of jet aircraft and engines, semiconductor microelectronics, computers and computer-controlled machine tools, pharmaceuticals and biotechnology, advanced energy and environmental technologies, advanced materials, and a host of other commercially successful technologies."

This system for supporting R \& D worked well when national security concerns generated sufficient support for funding myriad types of $R \& D$. The end of the Cold War, however, decreased the demand for defense research and made national security a less compelling reason to support $R \& D$. In addition, in the mid-1980s, the slowdown in U.S. productivity growth and the increasing competitiveness of U.S. trading partners led to a belief that the federal government should do more to help firms transfer research results in the laboratory to products in the market. These conditions led to a new push for public-private partnerships intended to support commercial R \& D. Much of the groundwork for these partnerships was laid in the $1980 \mathrm{~s}$. The Clinton administration seized on these ideas and expanded public-private commercial $R$ \& D partnerships greatly, making them the centerpiece of its technology program.

The next sections discuss the rise of these programs, the largest such publicprivate partnerships, and the promises and pitfalls associated with this new approach to funding R \& D.

\section{A NEW APPROACH: PUBLIC-PRIVATE TECHNOLOGY PARTNERSHIPS}

Previously, we explained why some form of public support for research is desirable-without that support there will be underinvestment in R \& D. There remains the question of what form that support should take. The concept of partnership has increasingly come into vogue. The concept suggests a relationship in which each partner is assigned specific responsibilities and given incentives and resources to fulfill those responsibilities. Partnerships work best when there are common shared objectives, but they may still be effective even when interests are disparate. When the partners have separate interests, however, more attention needs to be placed on the incentive-accountability structure. Public partnership policy is concerned with designing the terms of the partnership in ways that fulfill public objectives that are within the limits of available public resource constraints and that take into account private incentives and public political processes. The latter has received increasing attention. The government not only must have incentives to fulfill its commitments (responsibilities), but the public policy must be politically sustainable; that is, it must receive the necessary electoral support. (The problem of public commitment is especially important, because sovereign governments often cannot bind themselves with 
contracts in the same way that private parties, which rely on the government for contract enforcement, can). ${ }^{6}$

Partnerships in applied technology research generally take two forms. The first involves government funding of industrial $R \& D$. The second involves government and industry scientists actually working together. The common theme of these two types of partnerships is promoting research, not necessarily to meet government objectives, but to help the private sector move research from the lab to the market. These programs are controversial. Proponents contend that they address a legitimate need-helping firms undertake research that is too risky or expensive for a firm to do by itself. Such research can lead to innovations that are net benefits to society, but would not have been profitable to the firm. Opponents contend that these programs result in government attempting to pick winners-second-guessing the market about which technologies will be successful.

Ironically, underlying the current drive for public-private partnerships is the widespread belief that government is not very effective in choosing good projects (i.e., picking winners) and managing research. The evidence for this perspective is far from clear. Certainly, government support and conduct (and dissemination) of agricultural and medical research is widely viewed as highly successful. Similarly, in the key area of telecommunications, government support has been vital, from the first telegraph line between Washington and Baltimore in 1842 to support of the Internet.

The close connection between firms that do research and firms that market gives some credibility to the view that the private sector may have a comparative advantage in the conduct of applied research. Today's technology partnership typically entails government support for research that is initiated and conducted primarily by the private sector. The point is that the rationale for government intervention is not that the government is better than the private sector at picking winners, but that there exist important spillovers, even for applied technology. The objective of the government is thus to identify winning projects that would be privately unprofitable but socially beneficial because of high spillovers.

Figure 1 can help us evaluate the effectiveness of a partnership. The figure shows the expected returns to research projects in two dimensions, social and private. The expected total returns to a project are the sum of the expected social and private returns. Government support can have several possible outcomes as follows:

- In some cases, government support goes to inframarginal projects-high return projects that would have been undertaken anyway (projects in Area C). In that case, the government support is just a transfer payment. It has no allocative effect (other than the distortions caused by raising the revenue).

- Some of the money may go to marginal projects (projects in Areas A and B-projects that firms will not undertake on their own). If the government cannot identify spillovers, then the subsidy causes firms to undertake some projects that are (at the margin) unproductive (i.e., projects in Area A, which have no positive spillovers), and also some projects that (at the margin) have a total return in excess of the 


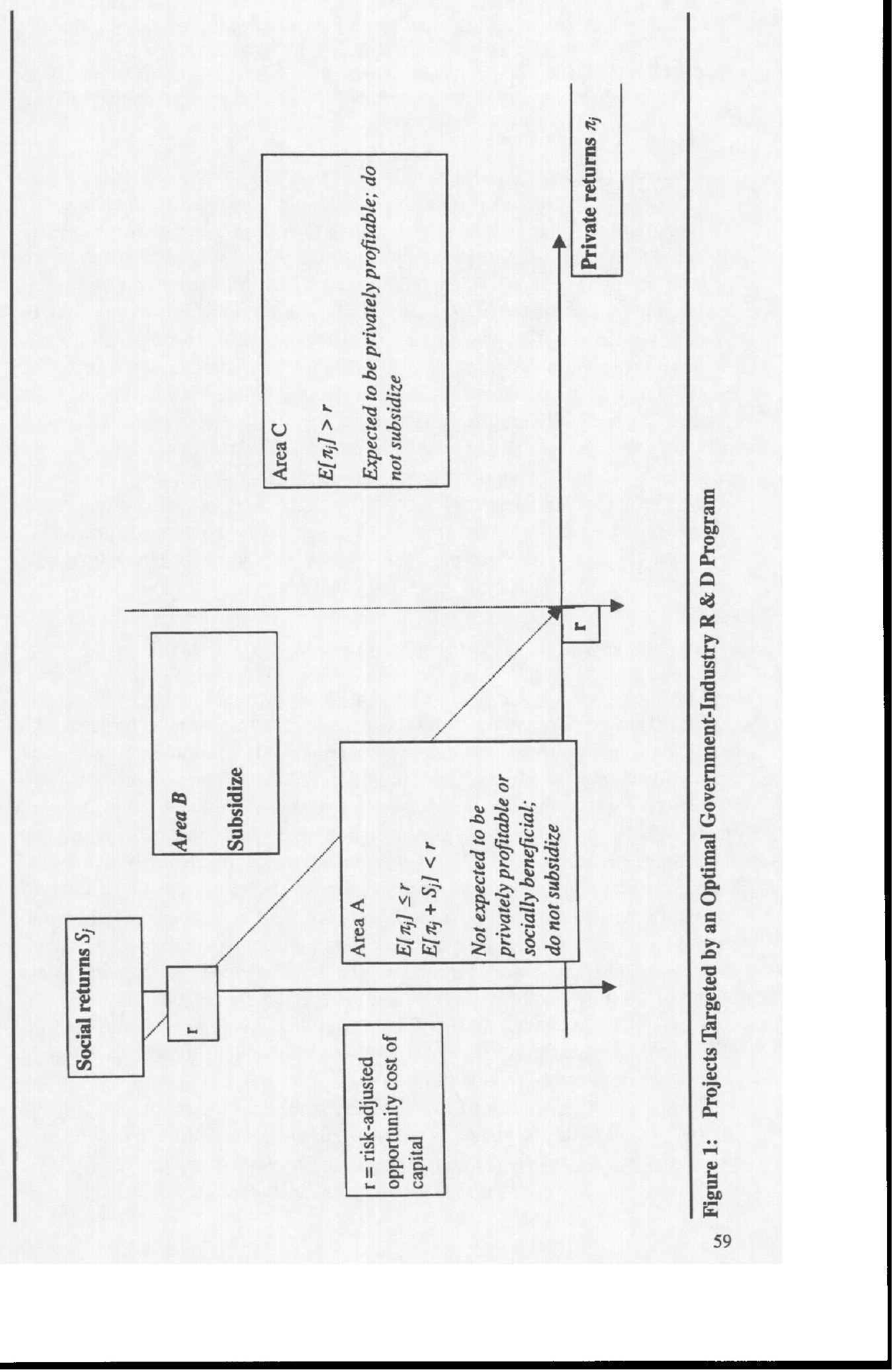

Reproduced with permission of the copyright owner. Further reproduction prohibited without permission. 
opportunity cost of capital and would not have otherwise been undertaken (i.e., projects in Area B). The net social benefit in this case is ambiguous.

- If the government is very effective in identifying projects with social returns not captured by the private sector (i.e., projects in Area B), then the support unambiguously increases economic efficiency.

There are further ambiguities in the effects of government support. If there were no spillovers, limited available resources (e.g., key research personnel) for research, and if the government were worse than the private sector in picking winners, then the government would distort the direction of research into less productive areas. On the other hand, the reward structure for government research managers or project selectors and those in the private sector may be markedly different. The private sector participates in the upside potential of research projects - when successful they can reap tremendous rewards. The upside potential for public officials, however, is far more limited. There is, not surprisingly, more of a culture of risk taking in the private sector than in the public, partly as a result of these reward structures. The consequence is not that the government is bad at picking winners, but that it places too much attention on picking projects that have a high probability of success, foregoing projects that have even higher expected returns, but have a lower probability of success. To the extent that this is true, and that there are limited resources for research, government research support may lower expected returns.

\section{IMPLEMENTATION AND EVALUATION ISSUES}

Consider again Figure 1. Recall that a government technology partnership program is more effective the better it can fund projects in Area B (projects with relatively high spillovers and low private returns). It is not clear how best to accomplish this goal. Most of these programs require industry to propose projects and the government to decide whether to subsidize them. Often, government subsidies are less expensive than capital from other sources, meaning that firms may be tempted to look to government before looking to other sources for financial support. In other words, there is no reason to believe that firms will propose only research projects in Area B (see Figure 1). Firms may be tempted to propose a project that falls anywhere in Figure 1 as long as they expect the subsidized project to be privately profitable. It is up to the government to determine which of these research projects would benefit society but would not be privately profitable without a subsidy. This means that government should not simply fund the best proposals it receives. Instead, it should fund the best among those that could not be funded elsewhere.?

Program managers who make funding decisions must reject not only projects of dubious scientific and technical merit, but also reject scientifically sound proposals that are very likely to yield commercial successes and therefore could be funded elsewhere. The obvious theoretical way to encourage this behavior is to 
build the proper incentives into these programs. Program managers should be rewarded for funding projects on the margin - those that are socially beneficial but would not be undertaken without a subsidy — and punished (or at least not rewarded) for funding inframarginal projects-those that firms would undertake without a subsidy.

In practice it is difficult to implement such a mechanism. First, observers must recognize that $\mathrm{R} \& \mathrm{D}$ is inherently risky, and any program that attempts to fund research projects that firms will not undertake will ultimately fund some projects that fail. Indeed, if the program funds only successful projects, it probably is not taking enough risks. But government-industry R \& D programsespecially those aimed at commercialization-are controversial. Program supporters may be reluctant to allow many failures for fear that opponents will point to individual project failures as evidence of program failure. Likewise, managers may not feel comfortable rejecting the most promising proposals, either because they want to increase the chances of achieving commercial success or because it puts them in the position of rejecting proposals that are too good.

Second, the only way to implement an incentive mechanism of the sort mentioned above is to include a comprehensive evaluation mechanism as part of the program. That is, properly rewarding and punishing program managers is possible only if there is some way to detect what type of projects they fund. Evaluating technology programs is technically very difficult. A comprehensive evaluation would combine complicated scientific knowledge with economic analysis under conditions of uncertainty. In any event, as Adam Jaffe (1998) notes, technology programs have never been designed with economic evaluation in mind. Without some comprehensive evaluations, public debates on these programs tend to focus on easily measurable private returns and easily understandable anecdotal stories of project success and failure.

Even if the technical obstacles to conducting comprehensive evaluations can be overcome at a reasonable cost, political factors may decrease the likelihood that these programs can be implemented efficiently. The politics of technology spending are similar to those of other issues. Cohen and Noll (1991) point out that politicians face incentives to treat technology programs like they do any other government spending - as a way to reward constituents, not to correct market failures. Indeed, Cohen and Noll conclude that the "overriding lesson from the case studies is that the goal of economic efficiency-to cure market failures in privately sponsored commercial innovation-is so severely constrained by political forces that an effective, coherent national commercial R \& D program has never been put in place" (p. 378). Politicians who favor allocating technology funds on the basis of constituencies may object to comprehensive evaluations, which have the potential to highlight funds allocated for reasons other than economic efficiency.

On the other hand, these programs cannot ignore constituency issues if they are to survive. Programs that attempt to select projects only on their economic 
and scientific merits may never develop a constituency and, thus, political support. Such programs may either be eliminated or changed to build support. This creates a potential Catch-22 situation: A program that allocates funds to reward constituencies may be popular, but will be less effective at correcting a market failure, whereas a program that attempts to correct a market failure may never develop a constituency and ultimately be canceled.

Finally, these programs raise other important questions that have yet to be dealt with fully. For example, how do we balance a firm's need for secrecy involving its research with society's desire to disseminate widely the results of publicly funded research and to evaluate the programs? Firms will not participate in these programs if results are immediately made available. On the other hand, making publicly funded research results available to only a few firmswhich may profit enormously from them-puts the government in an awkward position. Moreover, the programs cannot be evaluated without access to information, and they are much more likely to be susceptible to political manipulation if not evaluated properly.

Another important question is how costs and benefits should be shared. Both to enhance private sector incentives and to enlist private sector judgments in making project selections, these partnerships are beginning to require greater equity contributions by the private sector. A common suggestion (e.g., Branscomb \& Keller, 1998) is to require firms to bear costs in proportion to a project's expected private benefits. By requiring the private sector to put up considerable equity, it enlists the private sector in identifying winners, enabling government to focus on ascertaining the magnitude of spillovers. In addition, the reasoning goes, by contributing to project costs, the firm demonstrates its commitment to the project.

Although cost-sharing appears to be an attractive - and fair-proposition, in reality it raises many additional and as yet unanswered questions. First, estimating $e x$ ante the private and social benefits of a project is a monumental task. The task is made even more difficult by information asymmetries. The firm will have far more information about the potential market success of an innovation than will the government, and the firm has an incentive to predict market success in a way that increases the probability of receiving a government subsidy. Second, cost sharing could have a perverse impact on the types of projects industry proposes to government. Although cost sharing may indicate a firm's commitment to a research product, it also indicates the firm's belief that the project is more likely to yield a commercial success. By requiring cost sharing, therefore, the government may actually be less likely to fund projects for which there is a market failure. Whether this hypothesis is true is yet to be seen. The point is that it is not necessarily true that cost sharing will increase program effectiveness. Cost sharing will affect incentives, but empirical analysis is necessary to determine precisely what the effects are.

In the following discussion, we will look more carefully at the impact of various government programs for the support of research. Unfortunately, many of 
these programs were started too recently and have funded too few projects to allow for reliable assessments. Moreover, although some of the analyses described below focus on the impact of the programs on the level of expenditure, few provide much insight into the more fundamental questions of the quality of research expenditures.

\section{GOVERNMENT-INDUSTRY R \& D PROGRAMS: EXAMPLES AND EVALUATIONS}

Much of the legislative groundwork for today's public-private technology programs was laid in 1980. The Stevenson-Wydler Technology Innovation Act of 1980 "granted broad authority to the Department of Commerce "to enhance technological innovation for commercial and public purposes . . . including a strong national policy supporting domestic technology transfer and utilization of the science and technology resources of the federal government.' In addition to leveraging the economic impact of federal R \& D investments, StevensonWydler directed the federal government to conduct a wide range of research and cooperative activities to assess and improve American technological competitiveness" (Brody, 1996, p. 26). The Bayh-Dole, or University and Small Business Patent Procedure Act, of 1980 reformed government patent policy. BayhDole allowed government grant recipients and contractors to retain ownership rights to government-funded innovations. The act also encouraged universities to license innovations to firms (National Science Foundation, 1998).

Although those key pieces of legislation were put in place in 1980, it was not until the mid-1980s that public-private technology partnerships began to materialize, and not until the Clinton administration took office that they became a central part of federal technology policy. The new administration believed that "only the private sector has the skills and abilities to manage the complex process of developing new technologies and bringing them to market, while... [the] government plays a vital role in enabling the private sector's efforts" (Executive Office of the President, 1996, p. 42). Indeed, a central tenet of the administration's technology policy was that "the Federal government must encourage the development, commercialization, and use of technology" (Executive Office of the President, 1996, p. 42).

Technology partnership programs come in two forms, direct government funding of private $\mathrm{R} \& \mathrm{D}$ and direct collaboration between government and industry scientists. The most prominent of the first type are the Small Business Innovation Research Program (SBIR Program), the Advanced Technology Program (ATP), and Sematech (which stopped receiving funds in FY 1997, but then entered into a partnership of the second type). The second type includes Cooperative Research and Development Agreements (CRADAs), the Partnership for a New Generation of Vehicles (PNGV), and the Manufacturing Extension Partnership (MEP). Table 2 shows funding for the SBIR Program, ATP, MEP, and 
TABLE 2: Funding for Government-Industry Technology Programs-A Partial List

\begin{tabular}{|c|c|c|c|c|}
\hline \multirow[b]{2}{*}{ Year } & \multicolumn{4}{|c|}{$\begin{array}{l}\text { Program } \\
\text { (all figures in millions of current dollars) }\end{array}$} \\
\hline & $S B I R^{\mathrm{a}}$ & $A T P^{\mathrm{b}}$ & $M E P^{c}$ & $P N G V^{d}$ \\
\hline 1983 & 44.5 & & & \\
\hline 1984 & 108.4 & & & \\
\hline 1985 & 199.1 & & & \\
\hline 1986 & 297.9 & & & \\
\hline 1987 & 350.5 & & & \\
\hline 1988 & 389.1 & & 5.0 & \\
\hline 1989 & 431.9 & & 7.5 & \\
\hline 1990 & 460.7 & 10 & 8.7 & \\
\hline 1991 & 483.1 & 37 & 13.8 & \\
\hline 1992 & 508.4 & 49.4 & 17.0 & \\
\hline 1993 & 698 & 67.9 & 18.2 & \\
\hline 1994 & 717.6 & 199.1 & 30.2 & Not available \\
\hline 1995 & 948.9 & 340.5 & 74.2 & 223 \\
\hline 1996 & 974 & 221.0 & 80.0 & 241 \\
\hline 1997 & 1,269 & 253 & 95.0 & 263 \\
\hline 1998 (estimated) & & 199 & 113.5 & 281 \\
\hline 1999 (estimated) & & 269 & 106.8 & \\
\hline
\end{tabular}

a. Source: Small Business Administration and authors' calculations.

b. Source: ATP (1998), Office of Management and Budget (1998).

c. Source: MEP (1998).

d. Source: Office of Management and Budget $(1996,1997)$.

PNGV from their inception through the present. We will next describe these programs and discuss the available evidence on their effectiveness.

\section{THE SBIR PROGRAM}

The SBIR Program, established by the Small Business Innovation Development Act of 1982, was perhaps the first among the new wave of government programs intended to support private commercial $R \& D$. This act required federal agencies with extramural (i.e., contract and grant) R \& D budgets of over $\$ 100$ million per year to set aside a certain percentage of that budget to SBIR Program grants. The set aside increased from $0.2 \%$ of the annual extramural budget in FY 1982 to $1.25 \%$ of the budget by FY 1986 . By 1986, the SBIR Program budget was almost $\$ 300$ million per year. The SBIR Program was renewed in 1992 and expanded dramatically. Congress increased the set aside to $2.5 \%$ of the agencies' extramural budget by FY 1997 , causing SBIR Program funding to break the $\$ 1$ billion mark that year.

SBIR Program grants are intended to encourage commercialization of innovations by small firms (i.e., firms with 500 employees or less). Eligible firms submit research proposals to participating federal agencies, which use a competitive review process to make funding decisions. Firms can first apply for up to 
$\$ 100,000$ to determine "the scientific and technical merit and feasibility of ideas." If successful, they can then apply for up to $\$ 750,000$ to "further develop the proposed idea." Finally, the firm is expected to commercialize a product, although no additional SBIR Program funds are provided for that purpose. ${ }^{8}$ The firm retains intellectual property rights to its innovation and all profits from commercialization, although the government retains a license for government use.

The U.S. General Accounting Office has reviewed the SBIR Program several times (e.g., U.S. General Accounting Office, 1989, 1992, 1995). These evaluations focus primarily on the commercialization rate of funded projects under the assumption that high commercialization rates imply a successful program. Such analyses ignore the possibility that some commercialized projects may not have required government support as well as the possibility that some projects that were not commercialized may have yielded large social returns. The focus on commercialization suggests that program managers may be rewarded for funding many successful projects. This system may induce managers to fund projects guaranteed to yield a commercial success. Firms may realize this and propose projects that they believe are more likely to yield a commercial success. As a result, the program could fund many very successful projects, but because they were selected on their expected probability of yielding a commercial success, these projects may not have needed government funding to begin with. Under that scenario, the program would support many successful projects, but would have no real economic impact.

Wallsten (1998a) found that firms that won SBIR Program grants reduced their own R \& D expenditures by approximately the amount of the government grant, and that grants did not increase employment or sales. The results suggest that these government grants may crowd out a firm's R \& D spending. That is, firms simply reduce their own $R \& D$ expenditures by the amount of the subsidy and put the money toward investments other than research. However, Lerner (1996) found that, for firms located in areas with high venture capital activity, those receiving SBIR Program awards increased employment more than those that did not receive the awards.

\section{THE ATP}

The ATP, although not the biggest government-industry commercial R \& D program in the government's portfolio, has attracted the most attention. The ATP was established under the authority of the Omnibus Trade and Competitiveness Act of 1988 and implemented by the Bush administration in 1990. According to this act, the ATP was established "for the purpose of assisting United States businesses in creating and applying the generic technology and research results necessary to (1) commercialize significant new scientific discoveries and technologies rapidly, and (2) refine manufacturing technologies" (Hill, 1998, p. 146). The ATP was initially funded at a relatively modest $\$ 10$ million, slowly increasing to $\$ 68$ million by FY 1993 . The Clinton administration 
seized the ATP as a key component of its technology policy and increased funding to approximately $\$ 340$ million by FY 1995 . The ATP has been controversial, and funding has fallen since 1995 , with only $\$ 181$ million appropriated for FY 1999.

Like SBIR, firms submit proposals to the ATP for research aimed at ultimately commercializing a product. ${ }^{9}$ According to the ATP (1998), it attempts to "foster enabling technologies that will lead to new, innovative products, services, and industrial processes. For this reason, ATP projects focus on the technology needs of U.S. industry, not those of government. The ATP is industry driven, which keeps the program grounded in real-world needs. Research priorities for the ATP are set by industry: for-profit companies conceive, propose, cofund, and execute ATP projects and programs based on their understanding of the marketplace and research opportunities." The ATP also attempts to encourage firms to combine research efforts and thus funds many research joint ventures. Firms retain all intellectual property rights from any innovation.

The ATP is among the newest of these programs, and as such, few evaluations have been conducted. Preliminary evidence, however, is mixed. Yager and Schmidt (1997) examined the ATP's selection criteria and concluded that the ATP had no built-in mechanism to select projects that require government funding. The U.S. General Accounting Office (1996) surveyed firms that won awards and near winners firms that were rejected in the final stage of the competition. The U.S. General Accounting Office concluded that the ATP funded both marginal and inframarginal projects. Unlike many other government-industry R \& D programs, however, the ATP has attempted to make economic evaluation a centerpiece of its implementation. The ATP holds regular conferences with economists and scientists in order to formulate ways to evaluate the program properly. In addition, recognizing that the program is new and itself an experiment, the ATP frequently rethinks the types of proposals it funds and how its funding should be allocated.

The ATP has faced more congressional opposition than any other technology program. In part, this opposition was simply the result of a Republican Congress attacking a program strongly identified with a Democratic president. But the opposition is not only the result of partisan politics. Some observers believe this opposition resulted, in part, because the ATP emphasized its role in mitigating market failure rather than in building a constituency. The ATP stated in 1996 that it aims to select "only those projects for awards for which it thinks the potential social rate of return . . . far exceeds the potential private rate of return on investment, and for which it thinks the private sector will either not do the project at all, or not within the critical time, or in the scale/scope necessary to realize the potential private benefits" (National Institute of Science and Technology, 1996, p. 4). In other words, the ATP's specific goal was to mitigate a market failure, not to reward or build a constituency. Because ATP had no natural constituency, it became an easy target for congressional critics of the administration, which had made ATP its flagship technology program. 
The ATP's political problems also highlight another problem facing any government program that must reject some industry proposals and fund others. Although the program is sensitive to the problem of picking winners, by rejecting some proposals it ends up picking losers-firms that may be put at a disadvantage because they did not get government funds. This creates resentment between firms that did not receive funding. From 1990 to 1995, ATP received 2,210 applications and funded only 280 projects (ATP, personal communication, February 28,1996$)$. Even if all these projects were rejected on legitimate grounds, the large number of rejections creates a large number of potential program enemies.

\section{SEMATECH}

Sematech was the first prominent example of government support of an industrial research consortium aimed at commercialization. Sematech is a government-supported industry consortium founded in 1987 to help shore up America's once-declining position in the semiconductor industry. The National Cooperative Research Act of 1984 paved the way for this consortium by loosening antitrust restrictions on industrial research collaborations. Sematech began as a consortium of 14 leading U.S. semiconductor-manufacturing firms. By participating in Sematech, otherwise competing firms pooled semiconductor R \& D efforts. Participating firms are required to contribute $1 \%$ of their semiconductor revenues to the consortium, with a minimum of $\$ 1$ million and a maximum of $\$ 15$ million. Firms are also required to send engineers to Sematech's facility in Austin, Texas for at least half a year.

The federal government, through the Defense Department's Advanced Research Projects Agency (ARPA), provided approximately half of Sematech's annual $\$ 200$ million budget through 1996 . This direct subsidy ended in FY 1997. Sematech now has 11 domestic members and, now that it no longer receives funds from ARPA, has established a wholly owned subsidiary, International Sematech, with five foreign firms as members. Although Sematech no longer receives a direct subsidy, it has maintained a connection with the federal government by entering a partnership with Oakridge National Laboratory (partnerships of this sort are discussed below). ${ }^{10}$

Sematech is often credited with reversing the fortunes of the U.S. semiconductor industry, but that hypothesis is difficult to test. The Sematech model may have promise. For example, it is consistent with Paul Romer's (1993) suggestion of creating self-organizing industry investment boards. Such boards could "combine the government's efficiency at solving free-rider problems with the market's effectiveness in selecting practical problems that offer the highest rates of return" (p. 361). Here, too, we see difficulties in implementing theoretically sound ideas. Irwin and Klenow (1996), for example, found that firms involved in Sematech reduced their $\mathrm{R} \& \mathrm{D}$ expenditures by approximately $\$ 300$ million per year. This reduction has positive and negative interpretations. On one hand, 
firms may have reduced spending on duplicative research. On the other hand, firms probably did not increase spending on high-spillover research. In addition, no research projects are completely duplicative-more than one firm working on similar problems may develop very different solutions or directions for future research.

\section{CRADAs}

Government-industry partnerships in which government and industry scientists work together for the purpose of commercializing a product is a new approach. The largest of these are CRADAs. CRADAs are formal agreements between the national laboratories and private firms. CRADAs are intended to help the national laboratories in their primary mission by building their technical capabilities and to help private industry by commercializing innovations produced in the labs (Cohen \& Noll, 1995). Traditionally, the national laboratories facilitated technology transfer to the private sector by publicizing research results. By contrast, information from CRADAs is closely held, and the private partner retains intellectual property rights to any innovation. The Clinton administration initially wanted the national laboratories to devote $10 \%$ to $20 \%$ of their budgets to cooperative work with industry (Clinton \& Gore, 1993). Unfortunately, data about CRADAs are exceedingly difficult to obtain. Available information reveals that the number of new CRADAs increased from about 500 in 1992 to over 1,100 in 1994 before beginning to decline in 1995 .

CRADAs have not been subject to any comprehensive economic analysis. In part, this lack of evaluation is the result of a lack of access to data. As Cohen and Noll (1995) note,

\footnotetext{
The government has been especially closed in providing solid information about CRADAs - a policy that was deliberately set in motion by the provisions of the enabling statutes that protect the confidentiality of the agreements. CRADA proposals and reports are exempted from the Freedom of Information Act, and the agreements bind the parties not to reveal any proprietary information brought to the CRADA or any research results that emanate from it, without their mutual consent. Whereas some agencies make the titles and partner identities available and, in some cases, the cost, agencies are not obliged to do so and will not if their partner objects. Moreover, none of the agencies responsible for managing the CRADA program regularly collects information about the extent of its CRADA activity, much less performance data about the joint project. Hence, nearly all the available information takes the form of raw 'CRADA counts' that do not differentiate between small, narrowly defined projects and massive, broad agreements with large industrial consortia. (p. 230)
}

Although the idea of CRADAs was initially popular across the political spectrum, implementation has led to many controversies. Most of them arise when a CRADA appears to be too successful. For example, the AIDS drug, AZT, was developed by Burroughs-Wellcome in a CRADA with the National Institute of 
Health (NIH). Burroughs-Wellcome initially priced the drug at $\$ 2,000$ to $\$ 10,000$ per year. This led the NIH to develop fair pricing clauses for its CRADAs, but has been unable to determine what "fair pricing" means. ${ }^{11}$

\section{PNGV}

Another large public-private partnership is the PNGV. This program began in 1993 as a collaboration between seven federal agencies, 20 federal laboratories, and the three big U.S. automobile manufacturers. The program's goal is "to develop an environmentally friendly car with up to triple the fuel economy of today's midsize cars-without sacrificing affordability, performance, or safety. The other two PNGV goals are (1) to significantly improve national competitiveness in automotive manufacturing, [and] (2) to apply commercially viable innovations to conventional vehicles" (PNGV, 1998). The PNGV has not received as much attention as other government-industry programs, although it receives over $\$ 250$ million annually from the federal government.

The PNGV has not been subject to any economic evaluation. Although PNGV may have overcome many technological hurdles in its quest for a more efficient automobile, nobody has been able to investigate what the real effect of PNGV has been. Indeed, the National Academy of Sciences (1998) "found it difficult to assess the efforts and resources applied to the PNGV program because no funding plan was made available" (p. 11).

\section{THE MEP}

The MEP is another part of the new push toward public-private technology partnerships. MEP is different from other programs in that it is not intended to produce any particular product. Instead, MEP consists of regional offices that provide small- and medium-sized firms with technical, technological, and business advice and help them form partnerships with other businesses or government agencies (MEP, 1998). Like some other programs, MEP began in 1988, but was very small for several years. In 1992, there were only seven MEP centers. By 1997 , MEP had 70 centers and an annual budget of almost $\$ 100$ million. Like CRADAs and PNGV, there have been no economic evaluations of MEP.

\section{CONCLUSIONS AND POLICY RECOMMENDATIONS}

The end of the Cold War brought with it a need to rethink the way the United States funds science and technology. Support for basic research remains strong, and many have voiced their belief that government must continue to support R \& $\mathrm{D}$ at universities and colleges. The question of how to support industrial R \& D best has proven sticky. Government, and the Clinton administration in particular, has chosen to focus on government-industry R \& D partnerships aimed at 
commercializing innovations. The administration has started a host of such programs and drastically increased funding to many others. These programs, however, remain controversial, and it is not yet clear that they can achieve their ambitious goal of mitigating a market failure.

The economics behind these programs is sound. Firms acting in their own best interests will invest less than the socially optimal level of R \& D. By subsidizing some $\mathrm{R} \& \mathrm{D}$, government can help mitigate this market failure. Sound theory, however, does not always translate easily into sound policy. Preliminary evidence on new government-industry technology programs suggests that they face a host of problems in terms of implementation, evaluation, and political support. Each of those issues impacts the other.

Checkered preliminary evaluations, however, should not necessarily be viewed as condemning either the programs or the idea behind the programs. Just as the outcome of R \& D itself is inherently uncertain, so too is the outcome of an $R$ \& D program. Large firms undertake a portfolio of $R \& D$ projects, recognizing that some projects will pan out and others will not. Likewise, government programs to support industrial R \& D should be viewed as a portfolio. Some of these programs may turn out to be successful whereas others will not. The failure of one program to generate benefits does not necessarily mean that another program cannot generate benefits.

\section{RECOMMENDATIONS}

The large gap between private and social returns on $R \& D$ suggests that government-industry $R \& D$ programs, if properly implemented, could potentially yield enormous benefits. These programs are new, which means that we have a lot to learn about how they should be run. If we are to determine what works and what does not, the programs must include evaluation mechanisms. Unfortunately, the government agencies in charge of these programs tend to resist efforts to conduct comprehensive evaluations. As a result, we know very little about whether the programs are meeting their objectives.

Federal agencies should be more open toward evaluation and should give more thought to what success really means in the context of governmentindustry R \& D programs. Simply noting that funded projects have a high commercialization rate does not demonstrate that government funding had any real impact. Likewise, a failed project does not mean that the program is a failure and a spectacular commercial success does not necessarily mean that the government should not have funded the project. To our knowledge, no program has been willing to release data that would facilitate a proper evaluation, much less actually implement the program in a way that facilitates evaluation. ${ }^{12}$ For example, most programs are unwilling to release even the names of firms that applied 
to the program and were turned down. Without that basic information, it is nearly impossible to determine whether government funding had any real effect.

Agencies should also think carefully about the incentives facing managers who run these programs. Too much emphasis on commercialization may cause a manager to fund the most commercially promising proposals, which may be the very proposals that do not need funding. On the other hand, criticism of very large commercial successes may make managers reluctant to fund research that they feel has some small probability of being a tremendous commercial success (but would not be funded by the private sector alone). Comprehensive evaluations may help on this score-if managers are not judged just on commercialization then perhaps the debate will shift away from focusing on simple anecdotes.

Government-industry $R$ \& $D$ programs are an innovative approach to solving a serious market failure. Whether the problems facing government-industry $R \& D$ programs can be overcome is still an open question. Much research needs to be done to determine how these programs can accomplish their goals. More thought needs to be given to the incentives affecting the behavior of politicians, program managers, and firms involved in these programs. If the problems can be overcome, these programs could contribute significantly to economic growth.

\section{NOTES}

1. See Griliches (1992) for a discussion of underinvestment. See Reinganum (1989) for a discussion of factors that can lead firms to overinvest.

2. See Griliches (1992) and Nadiri (1993) for overviews of the literature on spillovers and returns to $\mathrm{R} \& \mathrm{D}$.

3. Sometimes the term social returns embraces total benefits to society-the private returns as well as the value of spillovers. Here, we use the term in a more limited sense, to refer only to the benefits that are not appropriated by the innovator.

4. For discussions of these issues, see Stiglitz and Sah (1989) and Barzel (1995).

5. For a discussion of the R \& D tax credit, see Hall (1993).

6. See Masahiko, Murdock, and Okuno-Fujihara (1997) for a general discussion.

7. See Wallsten (1998b) for a more in-depth discussion of this issue.

8. Initially, a Phase I award was worth up to $\$ 50,000$ and a Phase II award was worth up to $\$ 500,000$. Congress increased these amounts when it renewed the SBIR Program in 1992 .

9. Although ATP has rules mandating small-firm participation, ATP competitions are open to firms of any size.

10. See Irwin and Klenow (1996) and Sematech (1998) for more information on Sematech.

11. Most of the information in this paragraph comes from Cohen and Noll (1995).

12. For example, Adam Jaffe (1998) notes that perhaps the best way to evaluate programs that solicit proposals is to randomize awards. Some percentage of selected projects would randomly not be funded and some percentage of rejected projects would be funded (with preliminary screening to ensure that truly ridiculous proposals were not funded). This randomization approach would generate control groups and help identify whether government funding was actually necessary in undertaking the research project. 


\section{REFERENCES}

Advanced Technology Program, National Institute of Science and Technology. (1998). [On-line]. Available: http:/www.atp.nist.gov/atp/overview.htm.

Barzel, Y. (1995). Productivity change, public goods and transaction costs: Essays at the boundaries of microeconomics. In M. Perlman \& M. Blaug (Eds.), Economists of the twentieth century series. Aldershot, U.K.: Edward Elgar Publishing, Limited.

Branscomb, L., \& Keller, J. (1998). Towards a research and innovation policy. In L. Branscomb \& J. Keller (Eds.), Investing in innovation (pp. 462-496). Cambridge, MA: MIT Press.

Brody, R. (1996). Effective partnering: A report to Congress on federal technology partnerships. Washington, DC: U.S. Department of Commerce, Office of Technology Policy.

Clinton, W., \& Gore, A. (1993). Technology for America's economic growth, a new direction to build economic strength. Washington, DC: Executive Office of the President.

Cohen, L., \& Noll, R. (1991). The technology pork barrel. Washington, DC: The Brookings Institution.

Cohen, L., \& Noll, R. (1995). Feasibility of effective public-private R \& D collaboration: The case of cooperative R \& D agreements. International Journal of the Economics of Business, 2, 223-240.

Council of Economic Advisers, Executive Office of the President. (1995). Supporting research and development: The federal government's role [On-line]. Available: http://www.whitehouse.gov/WH/EOP/CEA/econ/html/econ-rpt.html.

Executive Office of the President. (1996). Technology in the national interest. Washington, DC: Author.

General Accounting Office. (1989). Federal research: Assessment of Small Business Innovation Research Programs (GAO/RCED-89-39). Washington, DC: Govemment Printing Office.

General Accounting Office. (1992). Federal research: Small business innovation research shows success but can be strengthened (GAO/RCED-92-37). Washington, DC: Government Printing Office.

General Accounting Office. (1995). Federal research: Interim report on the Small Business Innovation Research Program (GAO/RCED-95-59). Washington, DC: Government Printing Office.

General Accounting Office. (1996). Measuring performance: The Advanced Technology Program and private-sector funding (GAO/RCED-96-47). Washington, DC: Government Printing Office.

Greenwald, B., Salinger, M., \& Stiglitz, J. (1990, April). Imperfect capital markets and productivity growth (Rev. 1991, March). Paper presented at the NBER Conference, Vail, CO.

Griliches, Z. (1992). The search for R \& D spillovers. Scandinavian Journal of Economics, 94, $29-47$.

Hall, B. (1992). Investment and research and development at the firm level: Does the source of financing matter? (National Bureau of Economic Research Working Paper No. 4096). Cambridge, MA: National Bureau of Economic Research.

Hall, B. (1993). R \& D tax policy during the 1980s: Success or failure? In J. Poterba (Ed.), Tax policy and the economy (Vol. 7). Cambridge, MA: MIT Press.

Hill, C. (1995, June 19). Private funds are unlikely to replace cuts in public funds for $R \& D$ in the U.S. (Available from the Institute of Public Policy, George Mason University, Fairfax, VA).

Hill, C. (1998). The Advanced Technology Program: Opportunities for enhancement. In L. Branscomb \& J. Keller (Eds.), Investing in innovation (pp. 143-173). Cambridge, MA: MIT Press.

Himmelberg, C., \& Petersen, B. (1994). R \& D and internal finance: A panel study of small firms in high-tech industries. Review of Economics and Statistics, 76, 38-51.

Irwin, D., \& Klenow, P. (1996). High-tech R \& D subsidies: Estimating the effects of Sematech. Journal of International Economics, 40, 323-344.

Jaffe, A. (1998). Measurement issues. In L. Branscomb \& J. Keller (Eds.), Investing in innovation (pp. 64-84). Cambridge, MA: MIT Press. 
Jones, C., \& Williams, J. (1997). Measuring the social return to $R \& D$ (Finance and economics discussion series). Washington, DC: Federal Reserve Board.

Lerner, J. (1996). The government as venture capitalist: The long-run impact of the SBIR Program. (National Bureau of Economic Research Working Paper No. 5753). Cambridge, MA: National Bureau of Economic Research.

Levy, D., \& Terleckyj, N. (1983). Effects of government R \& D on private R \& D investment and productivity: A macroeconomic analysis. The Bell Journal of Economics, 14, 551-561.

Manufacturing Extension Partnership. (1998). [On-line]. Available: http://www.mep.nist.gov.

Masahiko, A., Murdock, K., \& Okuno-Fujihara, M. (1997). Beyond the East Asian miracle: Introducing the market enhancing view. In A. Masahiko, H. Kim, \& M. Okuno-Fujiwara (Eds.), The role of government in East Asian economic development: Comparative institutional analysis (pp. 1-40). New York: Oxford University Press.

Nadiri, I. (1993). Innovations and technological spillovers. (National Bureau of Economic Research Working Paper No. 4423). Cambridge, MA: National Bureau of Economic Research.

National Academy of Sciences, National Research Council. (1998). Review of the research program of the Partnership for a New Generation of Vehicles: Fourth report. Washington, DC: National Academy Press.

National Institute of Science and Technology. (1996). Guidelines for economic evaluation of the Advanced Technology Program. Washington, DC: Government Printing Office.

National Science Foundation. (1998). Science and engineering indicators. Washington, DC: Government Printing Office.

Office of Management and Budget, Executive Office of the President. (1996). Budget of the United States government. Washington, DC: Government Printing Office.

Office of Management and Budget, Executive Office of the President. (1997). Budget of the United States government. Washington, DC: Govermment Printing Office.

Office of Management and Budget, Executive Office of the President. (1998). Budget of the United States government. Washington, DC: Government Printing Office.

Partnership for a New Generation of Vehicles. (1998). [On-line]. Available: http://www.ta.doc.gov/ pngv/introduction/intro.htm.

Reinganum, J. (1989). The timing of innovation: Research, development, and diffusion. In R. Schrnalensee \& R. Willig (Eds.), Handbook of industrial organization (pp. 850-908). New York: Elsevier Science Publishers.

Robson, M. (1993). Federal funding and the level of private expenditure on basic research. Southern Economic Journal, 60, 63-71.

Romer, P. (1993). Implementing a national technology strategy with self-organizing industry investment boards. Brookings Papers: Microeconomics, 2, 345-399.

Schumpeter, J. A. (1939). Business cycles: A theoretical, historical, and statistical analysis of the capitalist process. New York: McGraw-Hill.

Sematech. (1998). [On-line]. Available: http://www.sematech.org.

Stiglitz, J. (1988). Economics of the public sector (2nd ed.). New York: Norton.

Stiglitz, J., \& Sah, R. (1989). Technological learning, social learning and technological change. In S. Chakravarty (Ed.), The balance between industry and agriculture in economic development (pp. 285-298). New York: Macmillan.

Wallsten, S. (1998a). Rethinking the Small Business Innovation Research Program. In L. Branscomb \& J. Keller (Eds.), Investing in innovation. Cambridge, MA: MIT Press.

Wallsten, S. (1998b). Can government-industry $R \& D$ programs increase private $R \& D$ : The case of the Small Business Innovation Research Program. Unpublished doctoral dissertation, Stanford University.

Yager, L., \& Schmidt, R. (1997). The Advanced Technology Program: A case study in federal technology policy. Washington, DC: AEI Press. 